\title{
Factors Shaping Attitudes towards Niche Luxury Cars Resulting from Brand Extensions
}

\author{
Dr. Vladimir Sashov Zhechev \\ University of Economics-Varna \\ Dr. Evgeni Stanimirov \\ University of Economics-Varna
}

\begin{abstract}
Global business has witnessed multiple automotive companies being positioned as niche market players. Such organizations are more frequently prone to apply inhomogeneous marketing approaches to meet some contemporary customers' desires for change and innovation. Such actions can modify customers' overall evaluation of the brand. In this regard, behavioral, cognitive, and affective aspects of attitude shall be monitored and continuously calibrated. In particular, self-image, conformity, and desire for uniqueness are purported to be among the key influencers of attitude alterations in luxury market segments. This brings questions about empirical testing of different attitudinal variables for the purposes of market offering to forefront of managerial discussion of automotive companies.This article delves into the factors that shape consumer attitudes towards niche car brands of class " $F$ " on the Bulgarian new cars market. It makes reference to some critical aspects that can steer change in the way these brands market themselves and attempts to identify the shifting nature of consumer attitudes related to niche luxury car purchase and ownership. The main objective of the paper is to present part of the findings of a broader study on the image effects from downward brand extensions by putting a special emphasis on the variables, shaping the attitudes towards niche car brands. It also presents some conceptual and methodological aspects that can be used for studies in other industries (e.g. consumer electronics, luxury apparel, etc.). The article holds practical value for market players as it tries to classify multipliers of success for companies practicing nichemanship.
\end{abstract}

Keywords: Brand Attitude, Luxury Cars, Niche Marketing.

\section{INTRODUCTION}

Building and enhancing brand equity through brand extension strategy is typical for the niche companies which aim at market and technological development. This is primarily valid for established brands where recognition and intangible benefits are expected to be translated to the extension. Brand extensions could reduce the high initial capital, required for the establishment of a new brand; could lower the distribution costs as well as the costs for media coverage. Thus the longterm marketing success is arguably secured by taking into 
account that brand awareness increases the sales prospects and the greater acceptance of the extensions (Singh, Scriven, Clemente, Lomax, \& Wright, 2012). Despite their advantages brand extensions should be implemented by taking into account the effects that they may produce. Some extensions could have a negative impact on the attitudes towards the main brand.

For the buyers of expensive products which bear luxury brands a significant importance is carried not only by the benefits that they receive, but also the idea of exclusivity that they get. Some customers of niche products believe that through the preservation of the exclusiveness of the brand image they could sustain their selfimage as well. Therefore they normally display negative reactions to extensions which raise the possibility of change in their attitudes and which may lead to brand image dilution (Magnoni \& Roux, 2012). This type of downward brand extension can potentially depreciate the brand meaning and change the attitudes toward it (Nesterkin, 2013).

Strong brands are characterized by higher demand which stimulates some niche companies to use that advantage to extend over the boundaries of their niche. Although this could generate some positive financial outcomes it could also cause negative effects on customers' attitudes and brand image. This, in turn, may reduce the exclusivity of the respective niche brand. However, companies rely on the increasing number of customers (also called "followers") who prefer to buy luxury brands irrespective of the product class. This poses some challenges for the companies involved in maintaining exclusivity for: (1) those seeking a high level of luxury or (2) switching to inclusiveness for the "followers" as this could have some financial and image projections.

The case of Class "F" car brands on the Bulgarian new cars market provides an interesting scientific and practical reason to investigate the above-mentioned challenges considering the transformation of the niche strategy and the changes regarding the attitudes that affect the business of niche companies. The existing scientific sources in the field of extensions reflect their impact on customers' supplier switching but do not pay attention to the long-term impacts on the attitudes towards the main brands. Companies of Class "F" have undergone significant transformation since their establishment. Although they are traditionally associated with the production of niche luxury cars of the highest (premium) class, throughout the last two decades they have converted from producers of a limited number of exclusive cars into market-oriented companies aiming at wider customer base. The discussed technological and image evolution is on the one hand a practical issue and on the other - it represents an interesting transition for the marketing theory and practice taking into account the changes resulting from the brand 
extension process. The process of downward brand extension on the consumer market of new niche luxury cars in Bulgaria reveals the impact that this strategy has on the attitudes towards the respective brands. In the country they are considered as carriers of higher social status, exclusivity and positive own image which determines the authors' interest to study the possible factors that shape the attitudes towards Class "F" car brands in the country. In this sense, objects of the research are the buyers of the niche brands of Class "F" on the Bulgarian new cars market. Subject of the research are the attitudes (cognitive, behavioral, affective) that are shaped by different personal, market and social factors.

The purpose of this article is based on scientifically-reasoned analysis, theoretical ideas and investigation of the change in the strategic orientation of companies from Class " $F$ " in Bulgaria and respectively the reactions of their clients, to develop and test methods for analysis and assessment of the attitudes towards niche luxury cars.

In the specialized literature the information regarding the changes in attitudes towards niche luxury cars is scarce. Furthermore there is a lack of such studies in Eastern Europe. This study is conducted under the following limiting conditions: 1) The respondents are customers of Class "F" brands within limited geographic territory (the Republic of Bulgaria). 2) The study is also limited in terms of product class.

\section{CONDITIONS AND STRATEGIC CONSIDERATIONS IN THE PROCESS OF DEVELOPING AND \\ IMPLEMENTING A NICHE MARKETING STRATEGY}

Currently, the positive and negative outcomes, arising from the implementation of the niche marketing strategy remain unclear. The increasing diversity in consumer tastes and habits together with the changing needs on consumer markets favor the activities of companies that are able to more precisely adapt their products to the requirements of the increasingly fragmenting markets. In this regard, the preconditions for the implementation of a niche marketing strategy could be based on: market deregulation; ineffective functioning of certain markets; inter-company capabilities; changes in consumer demands, etc. On the other hand, the necessity for implementation of such a strategy could be determined by: the saturation of certain markets; the lack of competitive advantages in some segments; low prices/deflation; increased competition; demand fluctuation, among others. The implementation of a niche marketing strategy must be consistent with the strategic company priorities and should not endanger the fundamental values and already built competitive advantages. 
Using niche marketing strategy companies develop strategic advantages by targeting specific market segments based on: 1) The unique desires of the consumers; 2) Customized products, designed to meet these desires; 3) Specific geographic location; 4) Better communication and coordination; 5) Flexibility; 6) Competitive advantage based on skills, experience and service quality; 7) Neutralizing direct rivalry with big companies on national and international markets (Parrish, Cassill, \& Oxenham, 2006).

Despite the positioning advantages related to the scope of the niche and their role for the market effectiveness of companies, firms with broad brand portfolios have different market behavior in comparison with those with more narrow specialization (Zhechev, 2012). To benefit from the advantages of the niche marketing strategy, companies must carefully select small-size markets and concentrate on the development of specialized practices (Wilson, 2012). Alternatively, Caragher (2008) notes that most copmanies start out as a small entities operating on single markets with limited geographic scope and in order to develop they repeatedly expand beyond the niche through detailed segmentation as they test their profitability on new markets. Zhelev (2010) explores a different aspect of that statement exploring the "double jeopardy" effect of the brands with narrower scope. The researcher notes that there are three types of "double jeopardy" that could be distinguished: behavioral, affective and cognitive and it can put smaller brands in an unfavorable competitive position to the bigger ones due to the lower volume of sold units and the potentially lower levels of customer loyalty. And although most companies, ideally aim to stop the expansion after reaching the optimum level of commitment and areas of service, this is often practically difficult to achieve (Rhee, Kim, \& Han, 2006). More and more often the experience and the business principles inevitably lead companies to risky and potentially harmful expansions (Sorenson, McEvily, Rongrong Ren, \& Raja, 2006)we propose that broad contemporary scope also provides insight into the routines that govern firm behavior. To attain broad scope, firms must repeatedly explore outside the boundaries 2016/1 of their current niche. Firms with broad niches therefore operate under a set of routines that repeatedly propel them into new market segments, expanding their niche. These niche expansions, however, involve risky organizational changes, behavior that disadvantages generalists relative to specialists, despite the positional value of broad scope. Empirical analyses of machine tool manufacturers and computer workstation manufacturers support this conjecture: (i. Thus companies with wide niches are characterized with a market shortcoming in comparison with their better concentrated competitors (Dobrev, Kim, \& Hannan, 2001). 
The results from the presented literature review reveal that the niche marketing strategy is primarily used in advanced industries and sectors rather than in emerging ones. An argument in favor of that statement is the fact that niches are often seen as a response to the increasing market competition, competitive pressure, demand fluctuations, etc. This provokes an interesting scientific and practical contradiction: if a mass manufacturer launches a niche product intended for a narrow range of consumers with specialized needs, would this product be correctly perceived by a firm practicing nichemanship that is closely specialized in the same field?

In this respect, authors adopt the view that the niche marketing strategy could be applied to mature markets as well as to developing markets as competitive pressure and demand could change dynamically in both types of settings. On the other hand, authors suppose that the niche marketing strategy is a complex one and consists of a multifaceted combination of product and market decisions. Thus the attitudes towards niche products expand their dimensions and could be regarded as specific to certain markets in accordance with geo-demographic and psychographic characteristics.

In conclusion, authors believe that by researching niche marketing strategies three main aspects should be take into account: 1) The market niche has a limited scope (Stanimirova, 2009); 2) The niche market could be protected by creating entry barriers (specific product qualities, forms of intellectual property, maintaining relationship with customers etc.); 3) The implementation of niche marketing requires specialized skills that contribute to the establishment of product differentiation and positive consumer attitudes.

\section{RELATIONSHIP BETWEEN ASSOCIATIONS AND ATTITUDES TOWARDS THE BRAND}

Brand associations are all elements rooted in consumers' mind that are connected with the brand and that reflect the reality accurately or inaccurately (Stanimirov \& Zhechev, 2013, p.74). Associations must be positive in order to generate positive customer attitude towards the brand.

Brand associations play a significant role in choosing a brand name as it should focus on an important feature or benefit that can justify the positioning process. Brand associations are formed as a result of: 1) Customers' contacts with companies and their employees; 2) Advertisements; 3) Publicity built on the spread of information by word of mouth; 4) The price at which products / services with certain brand are sold; 5) Associations with celebrities; 6) Product/ Service quality; 7) Product class/category to which the product belongs and 8) History and traditions of the manufacturing company (www.management studyguide.com, 2013). 
Positive brand associations could be realized in case the respective products are characterized as desirable, well marketed, popular etc. To achieve positive associations, the brand attributes must reflect on and respond directly to the customer needs. Positive brand associations increase company's competitiveness and entry barriers to potential rivals.

Keller (1993)brand awareness and brand image (i. e., a set of brand associations classifies brand associations into three major categories: attributes, benefits, attitudes (Figure 1):

Figure 1: Different types of brand associations

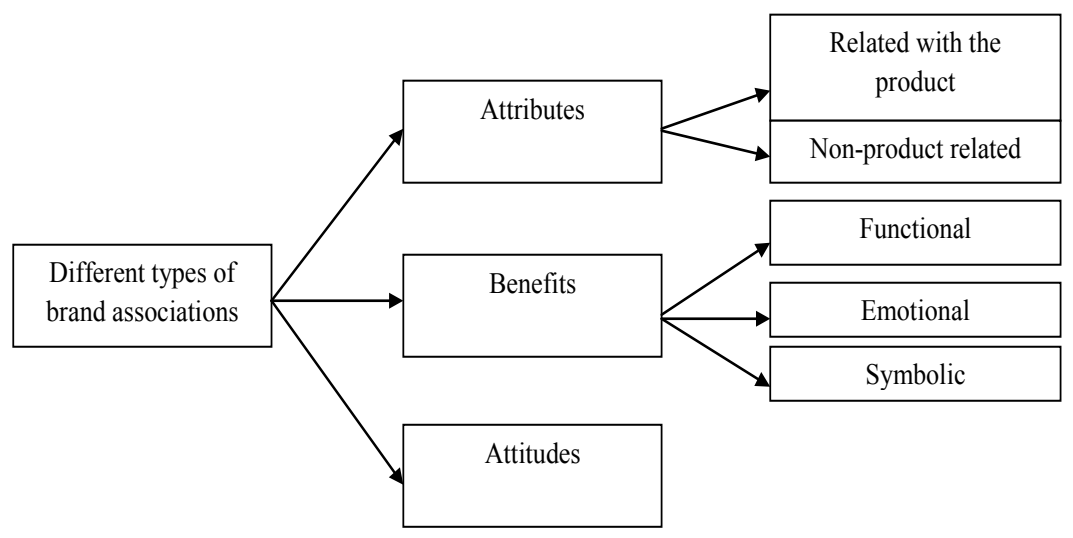

Attributes are descriptive functions that characterize the products/services or what consumers think these products/services represent and what their consumption is connected with. Attributes could be classified in two main categories: 1) product-related and 2) non-product related. The first group describes the physical composition of the product or the conditions of service delivery. The second group includes the external aspects of the product or service that are related to the purchase or the consumption, for example: information for the price (relation between quality and price range); packaging; image of the consumer of those products/ services (advertisements, public appearances); situations when the product is used (personally, with other people, in general public), etc.

Benefits reflect the personal customer value that purchasers refer to the attributes of the product/service (how exactly products/ services will be useful for them). In specialized sources of literature in the field (Park, Jaworski, \& Maclnnis, 1986) it is evidenced that there are three categories of benefits: (1) functional, (2) emotional, and (3) symbolic. Functional benefits refer to the key motivation factors (first and second level of Maslow's hierarchy of needs pyramid) and are directly connected with the product attributes. 
Emotional benefits are related to the product attributes as well and describe the feelings/emotions arising from the usage of the product/service. Symbolic benefits are related to the non-product related attributes and characterize the social approval and the selfexpression/external confidence. Thus customers could appreciate the prestige, the exclusivity and the brand fashion trends that meet their personal views.

Attitudes represent the overall consumer assessment of the brand. They are of significant importance as they often determine consumer behavior (for example brand choice). Also, if consumers are unable to evaluate the product they can use external features to draw conclusions about the quality on the basis of their knowledge about the brand (appearance, packaging, color). According to Hawkins, Best, \& Coney (2004) specialized literature has shaped the concept of attitudes as a three-component system: 1) affect (feelings towards the object of attitude); 2) behavior (willingness to act towards the object of attitude) and 3) cognition (knowledge and beliefs towards the object of attitude). Each component is important for the proper identification of attitudes as its importance can vary depending on consumers' motivation. It is therefore necessary to put these components in a hierarchical order so that the formation of attitudes could be better understood.

This study covers the extension strategy of niche luxury products by which consumers form attitudes based on complex factors such as: self-image relationship, need for uniqueness, fashion trends, conformity, etc. Taking into account the three components of attitudes, the authors evaluate how these factors influence the formation of attitudes. Based on these features it could be summarized that this study differentiates itself from and enriches previous scientific researches in the same field in that: 1) it aims to develop and test a methodology for analysis and evaluation of the factors shaping attitudes towards luxury brands, which could be applicable to industries such as: automobile trade, consumer electronics, IT products, luxury apparel, etc. 2) the study incorporates selected customers of niche luxury car brands; and subject of the study are the attitudes towards Class "F" cars.

\section{METHODOLOGICAL AND CONCEPTUAL} PREREQUISITES FOR STUDYING FACTORS FORMING THE ATTITUDES TOWARDS NICHE LUXURY CARS AS

\section{A RESULT OF EXTENSION}

The review of extant literature shows that there is a lack of researches in the field of downward brand extension of niche luxury cars and the factors shaping attitudes towards the main brands. While some studies analyze the potential differences between the consumer evaluations of extensions, defined as "functional" and 
"luxury", recent studies emphasize that this distinction may prove to be inadequate, as the latter vary widely based on the perceived prestige and price (Truong, McColl, \& Kitchen, 2009). In this respect it's important to clarify the influencing factors predisposing the downward extension of luxury cars and the resulting attitudes towards the main brands. The slowly growing demand, the nature of the competition (in regard to: cost price, time to launch to market, penetration in segments with high demand, offering multiple versions of a single model) and the consolidation of the business of different manufacturers are among the factors that determine the future of the car industry. The major trends that stand out in the field of brand extensions could be conditionally distinguished as consumer and organizational. Consumer ones could be summarized in: 1) The desire for individual movement (many variations of the same model are offered); 2) Cars are becoming an important means for self-expression and a place for communication, which is evident by the many additional options in equipment that are offered; 3 ) Systems linked to active safety, automated driving and advanced features for systems control in cars will continue to stimulate demand, providing distinction from substitutes. On the other hand, organizational trends in the field of downward extensions are related to: 1) Risk diversification due to do fluctuating sales in the upscale classes ("E and F");2) The expertise in the development and the supply of equipment as above, on the one hand, and the attractiveness of certain classes ("B and C" - with the highest shares in sales), on the other hand, are among the main reasons predisposing niche luxury brands to undertake a downward extension strategy; 3) The striving to capture a greater market share through detailed segmentation (brand market value). The existing academic sources in the field also outline that brands must satisfy functional (quality, reliability) and representative (emotional, symbolic) customer needs (de Chernatony \& McWilliam, 1990). In conclusion it could be assumed that in Bulgaria the representative needs prevail for luxury car brands, whereas for midscale cars most important appear to be the needs for practicality and functionality.

The population in this study is limited to customers (owners) of Class "F" vehicles on the Bulgarian new cars market. The approximate size of the population in the studied period (20082013 ) is 721 units. Of all distributed questionnaires (226) there were 111 completely filled out and returned. The degree of reliability of the scales for the variables set out in the conceptual model is tested using the Cronbach's Alpha criterion. The study of the relationships between the variables is calculated by $\chi^{2}$-analysis (aiming to exhibit a more detailed distinction between the factor and the resultant variables). The authors have applied 5-point Likert scales for all studied variables. The target respondents have been reached in two 
ways: (1) pre-selected using personal contacts in different regions of the country and (2) through authorized representatives (dealers) of new automobiles in Bulgaria. The main array of respondents is secured at the discretion of the dealerships as they are interested in the results of the study and actively promote the distribution of questionnaires.

\section{CONCEPTUAL MODEL OF THE STUDY OF FACTORS SHAPING ATTITUDES TOWARDS NICHE LUXURY CARS}

The study and evaluation of the factors shaping attitudes towards luxury automobiles represents a specific research process due to the multiple cultural, economic (among other) facets exerting influence on the owners of such vehicles in the country. In the development of the model (Figure 2) the authors have used ideas, concepts, components, and associative features explored by other researchers and practitioners related to investigation of the various aspects of attitudes and the influence of brand extensions over them.

The objective of the conceptual model is to gauge the potential influence of different factors that shape customer attitudes towards luxury automobiles in Bulgaria. A necessary condition for this study and influence measurement is the exploration of the standpoint of Class " $F$ " vehicle owners in the country.

The conceptual model sets out six generalizing variables that potentially affect customer attitudes (affective, behavioral and cognitive). (1) By the "self-image relationship" authors explore attitudes towards niche automobiles as the extant literature and practice in the field exhibits high attachment of customers' purchase and ownership of Class " $F$ " vehicles with their own image and/or the image of the people they want to be (Aaker, 1999).

Figure 2: Conceptual model of the study of the factors shaping attitudes towards niche luxury car brands

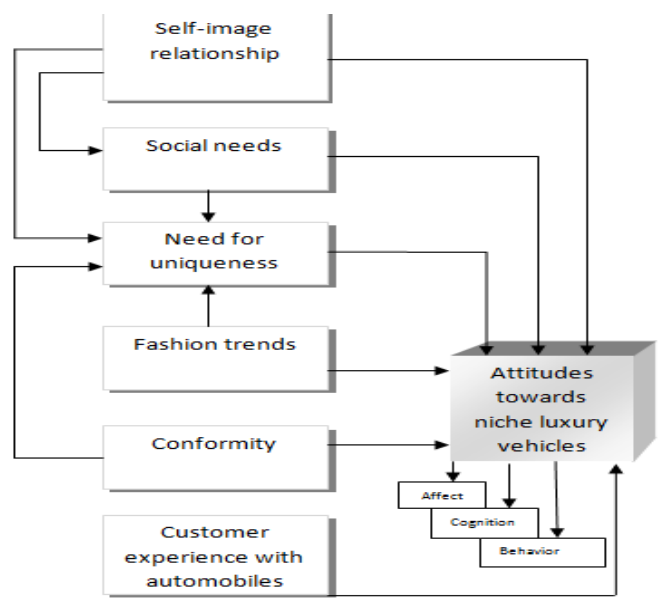


(2) „Social needs" - aims to determine whether the ownership of niche luxury car brands can reflect objectively customers' strive for higher achievement and respect by the reference groups they associate with (Kim, Ko, Xu, \& Han, 2012) (3) „Need for uniqueness” - intends to verify whether there is an inclination among customers to purchase and own automobiles that are unique in themselves and are perceived as such by others, and how this potentially impacts attitudes (Hem, De Chernatony, \& Iversen, 2003). (4) „Fashion trends" - this variable attempts to identify whether fashion in general and fashion trends in the automotive industry exerts influence over attitudes towards niche luxury car brands (H. Park \& Rabolt, 2009). (5) „Conformity” - aims to find out whether the change of behavior through which customers try to meet the influence of reference groups (accepting imposed norms and values) impacts the attitudes towards niche luxury cars (Keng, Jung, Jiuan, \& Wirtz, 2000). (6) "Customer experience with automobiles" - seeks to clarify to what extent the customer awareness about innovations in the automotive industry and respective country of origin of niche luxury automobile brands can potentially influence their attitudes. Overall, this study combines the well-acknowledged methods for evaluation the customer experience with automobiles by accentuating on: (1) innovations in the automobile industry and (2) the countries of origin of the studied niche luxury automobile brands of Class "F" on the Bulgarian new cars market.

\section{ANALYSIS OF THE SURVEY RESULTS}

Over $71 \%$ of all respondents indicate that the owned automobile correspond to their own image. The results related to the desire to own a car that reflects the perception of the person they would like to be further confirm the previous statement with high degree of agreement. A significant dispersion in discovered in the analysis of the "sense of importance", contributed by the ownership of niche luxury car. A possible reason for this is the perceived level of public significance of the participating respondents considering their social status that limits the importance generated only by the owned vehicle.

The majority of respondents reconcile around the statement that the owned automobile corresponds to their social needs. Essentially, 62\% of all respondents confirmed that the owned car corresponds to their social surroundings, while $52.2 \%$ indicate that there is a relationship between the vehicle they own and the respect they receive from their environment. Last, but not least, $32.6 \%$ of the respondents point out that their car serves a catalyst for higher achievements. These results match certain cultural features related to the emotional values of luxury cars and their place in the establishment of social image of their owners. 
The extant literature in the field has discovered that customers' "need for uniqueness" is a key determinant when purchasing image products. Survey participants do not regard their automobiles as unique neither do they share the desire to have their vehicle perceived as such. The authors of this paper come across discrepancies between respondents' estimates and the findings of the literature review in the field. This may be engendered by several factors, among which:

- There are likely to be other factors (different and / or more precisely defining uniqueness) predetermining respondents' disagreement;

- Since automobiles serve as catalyst for higher achievements, respondents may not be fully contented with the perceived uniqueness of the cars they currently own;

- The Bulgarian new cars market already prides itself on the presence of representatives of the so called "super cars" and niche upscale sports brands as Bugatti, Ferrari, Porsche, Rolls Royce and others. Since the latter are deemed exotic representatives of utmost quality and image, this might be considered a limiting factor for the perceived exclusivity of some Class "F" vehicles.

A wide range of the respondents consider the influence of fashion trends as neutral when choosing a car, but at the same time $59.4 \%$ of all participants agree that new models of luxury brands stimulate their purchase intention and interest. These results correspond to the findings of reviewed literature sources whereby fashion trends have been found to impact purchase decisions of image and luxury products.

The conceptual model incorporates a set of statements regarding the "conformity" variable. They aim to reflect the presence/absence of behavioral change as related to customers reacting to the influence of reference groups. The predominant part of the responses associated with social surroundings' influence when choosing a car are negative (29.7\%) and neutral (26.1\%). Interesting appears the fact that there is a dispersion in the statement, connected with the compliance with the image that social environment would built as a result of the choice of luxury car brand. The prevailing percentage $(27.9 \%)$ of respondents disagree with this statement, while a significant proportion (20.7\%) do agree that there is a link between their choice of vehicle and the alleged attitude of the social surroundings. On the premises of these results the authors arrive at the conclusion that respondents face little influence of conformity in choosing a niche luxury car brand, which may be caused by:

- Unwillingness to objectively acknowledge and recognize the influence of social surroundings on the choice of a car;

- The willingness of respondents to be different and distinctive (through possession of a more "classy" vehicle) in their social environment. 
The next set of statements encompasses customer experience with automobiles. The authors track down asymmetry in view of the high perceived experience with automobiles (50.4\%) The same holds valid for the awareness of respondents with innovations in the automotive industry (42.3\%). It is important to note that customers are largely interested in the country of origin of the respective niche luxury brands they own. There results further confirm that the surveyed customers are characterized both by high level of awareness and high familiarity of the innovations in the automotive industry.

The last set of statements in the conceptual model considers the three components of attitudes - (1) affective; (2) cognitive and (3) behavioral. The first component reveals high propensity of respondents to share positive emotions towards the niche luxury car brands they own. In view of the cognitive component, respondents to a large extent (36\%) express neutral judgment about the perceived limited range of clients for which their automobiles are designed (only $12.6 \%$ of all respondents agree fully that their car can be recognized as such). Different are the views of participants with regards to the behavioral component of attitudes. In particular, $68 \%$ are likely to choose the same brand on next purchase. The review of the results within this set of statements leads the authors to the following conclusions:

- Satisfied customers (those who share positive attitude) demonstrate inclinations to spread positive information about the owned car brands;

- The neutral opinion of respondents related to the perceived limited range of clients who can own the same niche luxury model can be explained by: (1) the general scarcity of publicly available information on sales of new luxury vehicles; (2) the differences of judgments of individual Class "F" brands incorporated in this study; (3) the lack of awareness of the ownership of such automobiles in other regions of the country;

- There is a tendency of increased attachment to the brand as evidenced by the high propensity for choosing the same brand upon next car purchase.

2016/1

\section{ANALYSIS AND DISCUSSION OF THE DIRECTION AND STRENGTH OF THE RELATIONSHIPS IN THE MODEL}

In order to move from binominal distribution to normal distribution the authors have employed the inverse trigonometric function arctangent (ATAN) for the transformation of the values from the SPSS code table.

As previously explained, the conceptual model incorporates the following generalizing variables: "social needs", "need for uniqueness", 
"fashion trends", "conformity" and "customer experience with automobiles". Table 1 presents the results of the regression analyses between the generalizing and the operationalizing variables.

The conducted regression analyses confirm the existence of relationships between the studied variables. For the "self-image relationship", $25 \%$ of the changes in the generalizing variable are attributed to changes in the "sense of significance" variable. These results could be due to lack of operationalizing variables that explain more precisely the relationship between the owned niche luxury car brand and the self-image.

Referring to the "social needs", only $19.5 \%$ of the changes in the generalizing variable can be explained by the congruence between the owned automobile and: (1) social surrounding, (2) respect and (3) strive for higher achievements. The strongest determinant of changes in social needs of the studied respondents is the third operationalizing variable - strive for higher achievements (39\% influence).

$26 \%$ of the change in the "need for uniqueness" is influenced by the operationalizing variable associated with the participants' personal perception of uniqueness of their automobile.

The fourth generalizing variable encompasses "fashion trends". It is noteworthy that due to the statistical significance of only one operationalizing variable the choice of automobile is largely influenced by whether the latter suits its owner.

The willingness of owners to have their vehicle desired by their social surroundings and the consideration of reference groups' judgments as related to the choice of automobile are carriers of respectively $33 \%$ and $67 \%$ (of the total $26 \%$ ) influence in the context of the "conformity" variable. Knowledge of innovations in the automotive industry is an essential influencing factor (41\%) under the "customer experience with automobiles" variable. In the context of this analysis country of origin has proved statistically insignificant variable (unlike the responses within the descriptive statistics).

The study of the relationships between generalizing variables and the different components of attitudes is also an interesting research viewpoint (Table 2). 


\section{S. Zhechev \& E.Stanimirov}

Table 1: Results of the regression analyses of the attitudes towards niche

\begin{tabular}{|c|c|c|c|c|c|c|c|}
\hline \multirow{2}{*}{$\begin{array}{l}\text { Generalizing/ } \\
\text { operationalizing } \\
\text { variables }\end{array}$} & \multirow{2}{*}{$\mathbf{R}$} & \multirow{2}{*}{$\mathbf{R}^{2}$} & \multirow{2}{*}{ Sig. } & \multirow{2}{*}{$\beta$-coefficient } & \multirow{2}{*}{ Weight (\%) } & \multicolumn{2}{|l|}{$\chi^{2}$} \\
\hline & & & & & & $\begin{array}{l}\text { Cramer's } \\
\text { V }\end{array}$ & Sig. \\
\hline $\begin{array}{l}\text { 1. Self-image } \\
\text { relationship }\end{array}$ & 0,505 & 0,255 & 0,000 & & & & \\
\hline $\begin{array}{l}\text { - perception of the } \\
\text { person I would like } \\
\text { to be }\end{array}$ & \multirow{2}{*}{\multicolumn{2}{|c|}{0,000}} & 0,237 & 0,119 & - & 0,380 & 0,000 \\
\hline $\begin{array}{l}\text { - sense of signif- } \\
\text { icance }\end{array}$ & & & 0,429 & $100 \%$ & 0,523 & 0,000 & \\
\hline 2. Social needs & 0,442 & 0,195 & 0,000 & & & & \\
\hline $\begin{array}{l}\text { - congruence be- } \\
\text { tween the automo- } \\
\text { bile and the social } \\
\text { surrounding }\end{array}$ & \multirow{3}{*}{\multicolumn{2}{|c|}{$\begin{array}{l}0,003 \\
0,000\end{array}$}} & 0,013 & 0,265 & $27 \%$ & 0,416 & 0,000 \\
\hline $\begin{array}{l}\text { - congruence } \\
\text { between the au- } \\
\text { tomobile and the } \\
\text { respect received by } \\
\text { others }\end{array}$ & & & 0.336 & $34 \%$ & 0,325 & 0,000 & \\
\hline $\begin{array}{l}\text { - congruence } \\
\text { between the au- } \\
\text { tomobile and the } \\
\text { strive for higher } \\
\text { achievements }\end{array}$ & & & 0,380 & $39 \%$ & 0,307 & 0,002 & \\
\hline $\begin{array}{l}\text { 3. Need for } \\
\text { uniqueness }\end{array}$ & 0,511 & 0,261 & 0,000 & & & & \\
\hline $\begin{array}{l}\text { - uniqueness of the } \\
\text { automobile }\end{array}$ & & & 0,000 & 0,511 & $100 \%$ & 0,458 & 0,000 \\
\hline 4. Fashion trends & 0,414 & 0,172 & 0,000 & & & & \\
\hline $\begin{array}{l}\text { - the choice of car } \\
\text { depends on the } \\
\text { suitability with the } \\
\text { individual owner's } \\
\text { perception }\end{array}$ & \multirow{2}{*}{\multicolumn{2}{|c|}{0,398}} & 0,002 & 0,351 & $100 \%$ & 0,400 & 0,000 \\
\hline $\begin{array}{l}\text { - interest upon } \\
\text { presentation of a } \\
\text { new luxury model }\end{array}$ & & & 0,093 & - & 0,276 & 0,006 & \\
\hline 5. Conformity & 0,511 & 0,261 & 0,000 & & & & \\
\hline $\begin{array}{l}\text { - willingness to } \\
\text { have a car that is } \\
\text { highly desired }\end{array}$ & \multirow{2}{*}{\multicolumn{2}{|c|}{0,000}} & $0,060^{*}$ & 0,189 & $33 \%$ & 0,354 & 0,000 \\
\hline $\begin{array}{l}\text { - considering the } \\
\text { judgments of the } \\
\text { social surrounding }\end{array}$ & & & 0,380 & $67 \%$ & 0,360 & 0,000 & \\
\hline $\begin{array}{l}\text { 6. Customer } \\
\text { experience with } \\
\text { automobiles }\end{array}$ & 0,640 & 0,410 & 0,000 & & & & \\
\hline $\begin{array}{l}\text { - innovations in } \\
\text { the automotive } \\
\text { industry }\end{array}$ & \multirow{2}{*}{\multicolumn{2}{|c|}{0,868}} & 0,000 & 0,629 & $100 \%$ & 0,515 & 0,000 \\
\hline - country of origin & & & 0,17 & - & 0,430 & 0,000 & \\
\hline
\end{tabular}


Table 1 Relationship between the attitudinal components and the generalizing variables

\begin{tabular}{|l|l|l|l|}
\hline \multirow{2}{*}{ Component of attitude } & \multicolumn{3}{|l|}{$\begin{array}{l}\text { (1) Self-image, (2) Social needs, (3) Need for uniqueness, } \\
\text { (4) Fashion trends, (5) Conformity, (6) Customer experience with } \\
\text { automobiles }\end{array}$} \\
\hline & $\mathbf{R}$ & $\mathbf{R}^{2}$ & Sig. \\
\hline Affective & 0,588 & 0,345 & 0,000 \\
\hline Cognitive & 0,627 & 0,393 & 0,000 \\
\hline Behavioral & 0,576 & 0,332 & 0,000 \\
\hline
\end{tabular}

The following conclusions can be drawn from these results: (1) "self-image relationship" holds the highest sway within the affective component of attitudes (37\%), followed by "fashion trends" (33\%) and "customer experience with automobiles" (30\%); (2) The dominant influence of the cognitive component is contributed by "fashion trends" (51.2\%), "conformity" (25.4\%) and "self-image relationship (23.4\%); (3) Under the behavioral component the highest weight ( $86 \%$ ) is carried by the "fashion trends" and 14\% are attributable to the "need for uniqueness".

The existing sources of literature in the field point out the role of the affective relationship between customers and brands. The affective component of attitudes is also connected with emotional attachment and personal identification with brands. After running the tests the authors highlight that the aforementioned results conform to the findings of other studies whereby the affective attachment diminishes customer propensity to switch to alternative brand (supplier) even in the presence of more attractive offer.

\section{RECOMMENDATIONS FOR FUTURE RESEARCH}

The study is conducted within a single country and includes respondents who own a niche luxury vehicle belonging to Class " $F$ " (according to the international automobile classification schemes). In addition to the results that this research reveals regarding customer attitudes towards niche luxury cars, future research may consider a similar study looking at other brands (in other industries such as: consumer electronics, IT, fashion products and accessories) using a wider range of operationalizing variables as this can increase the practical application of the conclusions reached across multiple businesses. Since Bulgaria embodies a complex synthesis of characteristics of supply and demand (V. S. Zhechev \& Stanimirov, 2013), an analogous study of other brands in different product classes can provide a conceptual basis for investigation of brand extensions' impact over resultant customer attitudes. The results of such analysis may serve similar research purposes in other geographic contexts. 
Future research may also examine some financial effects of downward brand extensions such as for instance whether the volume of the net long term profit from maintaining exclusive attitudes in a niche isn't lesser compared to the net long term profit achieved through "inclusivity". A study of this sort would require data on the number of buyers of luxury products of the highest respective class and their price ranges, as well as the number of buyers (who are potentially interested in lower class products of luxury brands) and the price ranges of downward extensions. Such study can provide valuable information on the key trends for the development of Class " $F$ " vehicles and outline strategic priorities for suppliers in terms of maximizing their long term profit.

Other practical issues that may be subject to future research are related to whether: (1) Bulgaria has exclusive elite buyers, i.e. customers who would only buy a niche luxury car brand if it bears special features and is offered at such price that makes it inaccessible for users with comparably lower purchasing power? What is the number of such buyers, what is the price they are inclined to pay, how much can be gained from them in the short and long run? Is this gain higher compared to the potential profit that can be achieved by launching downward extensions (inclusivity)?; (2) Does the country have venturesome buyers (innovators) who would still like to buy the most expensive niche luxury models acknowledging the fact that the supplier sells models of lower class and lower comparative prices, which are designed for customers "outside the elite segment"? What is the number of such buyers, what is the price they are inclined to pay, how much can be gained from them in the short and long run?; (3) Does the new cars market in Bulgaria include buyers (described as "followers") who would purchase downscale models of niche luxury car brands trying to "imitate" the elite customers and acknowledging the fact that the respective company sells its upscale models at prices that make them accessible for the latter buyers only? What is the number of such buyers, what is the price they are inclined to pay, how much can be gained from them in the short and long run?

Another important aspect which future studies can address is

Inquiry 2016/1

158 


\section{CONCLUSION}

In the context of the contemporary business development companies compete on the basis of the depth of consumer needs and desires knowledge. In this respect, positive attitudes can create functional, emotional and symbolic benefits to consumers, thereby deriving many challenges for suppliers of niche luxury vehicles in Bulgaria related to the desire of capturing a higher share of the market.

The proposed conceptual model uses a creative approach to the assessment and measurement of consumer attitudes, taking into account practical research findings of brand extensions and nichemanship in the field. The model can be applied to analysis of other industries/markets (consumer electronics, IT, designer products and accessories, etc.) which exhibit high degree of attitudinal decision making within the context of Marketing 3.0 and 4.0.

The authors arrive at the conclusion that thereis a high likelihood of automotive producers to induce "desired change in attitudes" as this can result in larger aggregated profit. Under the contemporary market circumstances in this industry it can be argued that the optimal changes of attitudes are potentially those whereby the total net profit is the sum of the net profit from "elite buyers" and the net profit realized from "inclusive followers". Logically, the equation must take into account the probable losses by the possible supplier switch of some elite buyers. Nevertheless, the question whether changes in attitudes could affect the performance of suppliers and their respective brands remains an important area that comes to the forefront of managerial discussions among executives of authorized dealerships in the country.

\section{REFERENCES}

Aaker, J. L. (1999). The Malleable Self: The Role of Self-Expression in Persuasion. Journal of Marketing Research (JMR), 36(1), 45-57.

de Chernatony, L., \& McWilliam, G. (1990). Appreciating brands as assets through using a two dimensional model. International Journal of Advertising, 9(2), 111-119.

Dobrev, S. D., Kim, T. Y., \& Hannan, M. T. (2001). Dynamics of niche width and resource partitioning. American Journal of Sociology, 106(5), 12991337. Retrieved from $<$ Go to ISI $>$ ://WOS:000169387400003

Hawkins, D. I., Best, R. J., \& Coney, K. A. (2004). Consumer Behavior: Building Marketing Strategy. Publish. Retrieved from http://www. amazon.com/dp/0072416882

Hem, L. E., De Chernatony, L., \& Iversen, N. M. (2003). Factors Influencing Successful Brand Extensions. Journal of Marketing Management, 19(September 2001), 781-806.

Keller, K. L. (1993). Conceptualizing, measuring, and managing customerbased brand equity. Journal of Marketing, 57(1), 1. http://doi. org/10.2307/1252054 
Keng, K. A., Jung, K., Jiuan, T. S., \& Wirtz, J. (2000). The influence of materialistic inclination on values, life satisfaction and aspirations: An empirical analysis. Social Indicators Research, 49(3), 317-333.

Kim, K. H., Ko, E., Xu, B., \& Han, Y. (2012). Increasing customer equity of luxury fashion brands through nurturing consumer attitude. Journal of Business Research, 65(10), 1495-1499.

Magnoni, F., \& Roux, E. (2012). The impact of step-down line extension on consumer-brand relationships: A risky strategy for luxury brands. Journal of Brand Management, 19(7), 595-608. Retrieved from http://dx.doi.org/10.1057/bm.2012.8

Nesterkin, D. a. (2013). Organizational change and psychological reactance. Journal of Organizational Change Management, 26(3), 573594. Retrieved from http://www.emeraldinsight. com/10.1108/09534811311328588

Park, C., Jaworski, B., \& Maclnnis, D. (1986). Strategic brand concept-image management. The Journal of Marketing, 50(4), 135-145.

Park, H., \& Rabolt, N. (2009). Cultural value, consumption value, and global brand image: A cross national study. Psychology \& Marketing, 26(8), 714-735. http://doi.org/10.1002/mar

Parrish, E. D., Cassill, N. L., \& Oxenham, W. (2006). Niche market strategy in the textile and apparel industry. Journal of Fashion Marketing and Management, 10(4), 420-432.

Rhee, M., Kim, Y.-C., \& Han, J. (2006). Confidence in Imitation: Niche-Width Strategy in the UK Automobile Industry. Management Science, 52(4), 501-513. Retrieved from http://mansci.journal.informs.org/ content/52/4/501.abstract

Singh, J., Scriven, J., Clemente, M., Lomax, W., \& Wright, M. (2012). New Brand Extensions. Journal of Advertising Research, 52(2), 234-242. http://doi. org/10.2501/JAR-52-2-234-242

Sorenson, O., McEvily, S., Rongrong Ren, C., \& Raja, R. (2006). Niche width revisited: Organizational scope, behavior and performance. Strategic Management Journal, 27(10), 915-936.

Stanimirova, M. (2009). Market niches in the agricultural field. GeaPrint, Varna. In Bulgarian: Станимирова, М. (2009). Пазарни ниши в аграрната сфера. "ГеаПринт", Варна).

Truong, Y., McColl, R., \& Kitchen, P. J. (2009). New luxury brand positioning and the emergence of Masstige brands. Journal of Brand Management, 16(56), 375-382. Retrieved from http://www.palgrave-journals. com/doifinder/10.1057/bm.2009.1

Wilson, J. (2012). Manage Your Niche Wisely. CPA Prac. Mgmt. F., 8, 5.

Zhechev, V. (2012). The role of nichemanship as opposed to mass marketing within the context of contemporary globalization. In Trends and Challenges in the economic development (Vol. 1, pp. 479487). University of Economics-Varna.

Zhechev, V. S., \& Stanimirov, E. (2013). The Impact of Brand Extensions on Brand Image Dilution Related to Nichemanship: An Example of Porsche in Bulgaria. International Journal of Professional Management, 8(6).

Zhelev, S. (2010). Again about the "double jeopardy effect and the demand patterns in brand performance. Economic Alternatives Journal, 3(34). In Bulgarian: Желев, С. (2010). Отново за „двойната застрашеност” и за търсенето на закономерности в поведението на брандовете. Сп. Икономически Алтернативи//бр, 3, 34. 